\title{
Fourier transform infrared microspectroscopy monitoring of 5-fluorouracil-induced apoptosis in SW620 colon cancer cells
}

\author{
YANFENG GAO $^{1 *}$, XIONGWEI HUO ${ }^{2 *}$, LIU DONG $^{2,3}$, XUEJUN SUN $^{2}, \mathrm{HE} \mathrm{SAI}^{2}$, \\ GUANGBING WEI ${ }^{2}$, YIZHUANG XU ${ }^{4}$, YUANFU ZHANG ${ }^{4}$ and JINGUANG WU ${ }^{4}$ \\ Departments of ${ }^{1}$ Anesthesiology and ${ }^{2}$ General Surgery, The First Affiliated Hospital of Medical College, \\ Xi'an Jiaotong University, Xi'an, Shaanxi 710061; ${ }^{3}$ Department of General Surgery, Shaanxi Provincial People's Hospital, \\ Xi'an, Shaanxi 710068; ${ }^{4}$ Beijing National Laboratory for Molecular Sciences, State Key Laboratory \\ for Rare Earth Materials Chemistry and Applications, College of Chemistry and \\ Molecular Engineering, Peking University, Beijing 100871, P.R. China
}

Received February 9, 2014; Accepted November 7, 2014

DOI: $10.3892 / \mathrm{mmr} .2014 .3088$

\begin{abstract}
Colon cancer is associated with a high incidence and a poor prognosis. The aim of the present study was to determine whether Fourier transform infrared (FTIR) microspectroscopy can be used to monitor the chemotherapy drug-induced apoptosis of SW620 colon cancer cells. The $50 \%$ inhibitory concentration $\left(\mathrm{IC}_{50}\right)$ of 5-fluorouracil (5-FU), the main chemotherapeutic agent used for the treatment of colorectal cancer, was determined as the inhibition of growth of the SW620 cells using an MTT assay. Cell starvation and 5-FU treatment synergized to arrest the cells in the G1 and S phases of the cell cycle. FTIR combined with fluorescence activated cell sorting (FACS) analysis were used to analyze the SW620 cells following treatment with 5-FU for 12,24 and $48 \mathrm{~h}$. The apoptotic cells had several spectral characteristics. The relative peak intensity ratio $\left(I_{1740} / I_{1460}\right)$ was significantly increased $(\mathrm{P}<0.05)$, the $\mathrm{I}_{1740} / \mathrm{I}_{1460}$ ratio, associated with a band of amino acid residues at $1,410 \mathrm{~cm}^{-1}$ was significantly increased at the early and late phases of cell death $(\mathrm{P}<0.05)$, the peaks at $1,240 \mathrm{~cm}^{-1}$ increased in wave number, a band at $1,040 \mathrm{~cm}^{-1}$, associated with polysaccharides, appeared at 24 and $48 \mathrm{~h}$ and then moved to a higher wave number and the $I_{1040} / I_{1460}$ ratio increased at the late stage of apoptosis. These results demonstrated that FTIR can be used as a label-free
\end{abstract}

Correspondence to: Professor Xuejun Sun, Department of General Surgery, The First Affiliated Hospital of Medical College, Xi'an Jiaotong University, 277 West Yanta Road, Xi'an, Shaanxi 710061, P.R. China

E-mail: sunxuejunsky@126.com

${ }^{*}$ Contributed equally

Key words: colon cancer, cell cycle, apoptosis, Fourier transform infrared, chemotherapy technique to monitor cancer cell apoptosis and to understand the spectral fingerprints of apoptotic cells. This suggested that FTIR spectral features have potential as a powerful tool to monitor cancer cell apoptosis.

\section{Introduction}

Cancer remains one of the major life threatening diseases in humans. Each year, almost 70,000 individuals between the ages of 15 and 40 years are diagnosed with cancer in the USA (1). Amongst all types of cancer, colorectal cancer is the second most frequent cause of cancer-associated mortality in developed countries and is the fifth leading cause of mortality in China (2,3). Surgery and chemotherapy are the main techniques used in the treatment of colorectal cancer and 5-fluorouracil (5-FU) is the chemotherapeutic agent of choice for its treatment (4). It has been widely used for the treatment of solid tumors, including colorectal, breast and head and neck cancer (5). On entering the tumor cell, 5-FU can exert cytotoxic effects via the inhibition of thymidylate synthetase (TS) or through incorporation into RNA and DNA, which lead to the activation of apoptosis (6,7). Apoptosis occurs as part of various normal and pathological processes and can be triggered by chemotherapeutic drugs (8). Apoptosis is the process by which cells self-destruct without evoking an inflammatory response and is characterized by nuclear and cytoplasmic shrinkage, chromatin condensation, internucleosomal DNA cleavage and plasma membrane blebbing $(9,10)$.

At present, colorectal cancer is monitored following chemotherapy using techniques, including electronic colon endoscopy, computer-assisted tomography and B ultrasonic imaging. The disadvantage of these approaches is of that auxiliary examination can only monitor the level of morphological changes, but not molecular changes, including gene mutations. Although molecular biological techniques focusing on the molecular mechanism of colorectal cancer have improved, there are few specific biomarkers and these techniques are time-consuming (11). Thus, it is important to develop an accu- 
rate, simple, rapid and non-invasive technique for the real-time monitoring of colon cancer chemotherapy at the molecular level.

Following advances in vibrational spectroscopy techniques, their application in medical biology is increasing (12). Fourier transform infrared spectroscopy (FTIR) has been used as an analytical tool in chemistry for several years. In addition, FTIR can be applied as a simple, rapid and non-invasive method to detect and identify cancer with minimal sample preparation and can be used for the qualitative identification and quantitative analysis of various components in a complex mixture (13). Few studies have monitored the morphology of cancer cells using vibrational spectroscopy (14-17) and, although several spectroscopic studies have examined the cell apoptosis, cell cycle, differentiation and proliferation of different cell lines and tissues $(18,19)$, there has been no detailed analysis of colon cancer cell apoptosis following treatment with chemotherapeutic agents. In the present study, the feasibility of FTIR spectroscopy analysis to identify different stages of tumor cells apoptosis was assessed to attempt to provide a theoretical basis for the application of FTIR spectroscopy in the monitoring of clinical chemotherapy.

\section{Materials and methods}

Cell lines and cell culture. The human colon carcinoma cell line SW620, also termed $\mathrm{CCL}_{227}$, which overexpresses TS, was purchased from the China Center for Type Culture Collection, (Wuhan, China) (20). The cells were grown in high glucose RPMI medium (Hyclone Laboratories, Inc., Logan, UT, USA) supplemented with $10 \%$ fetal calf serum (Gibco-BRL, Carlsbad, CA, USA) with penicillin and streptomycin (100 U/ml each; Sigma-Aldrich, St. Louis, MO, USA) in a humidified incubator with $5 \% \mathrm{CO}_{2}$ at $37^{\circ} \mathrm{C}$. All experiments were performed on exponentially growing cells. All cells were incubated with 5-FU (Sigma-Aldrich) for 12, 24 and $48 \mathrm{~h}$ to induce apoptosis.

5-FU treatment. The cells in $100 \mu \mathrm{l}$ culture medium per well were seeded into 96-well plates (Gibco-BRL) and cultured at $37^{\circ} \mathrm{C}$ for $24 \mathrm{~h}$. The culture medium was then replaced with serum-free medium and various concentrations of 5-FU (6.25, $12.5,25,50,100,200$ and $400 \mu \mathrm{M})$ were adjusted in the wells. Following additional incubation at $37^{\circ} \mathrm{C}$ for $24 \mathrm{~h}, 10 \mu \mathrm{l} \mathrm{MTT}$ (Sigma-Aldrich) dissolved in phosphate-buffered saline (PBS) at a concentration of $5 \mathrm{mg} / \mathrm{ml}$ was added to each well and the plates were incubated at $37^{\circ} \mathrm{C}$ for $4 \mathrm{~h}$. The medium was removed and $150 \mu \mathrm{l}$ dimethylsulfoxide (Sigma-Aldrich) was added to each well followed by agitation of the plates for $5 \mathrm{~min}$. The absorbance was then measured at $570 \mathrm{~nm}$ in a scanning spectrophotometer (Spectronic 20D; Milton Roy, Rochester, NY, USA). A total of six wells were used for each drug concentration and the experiment was repeated three times. The $50 \%$ inhibitory concentration $\left(\mathrm{IC}_{50}\right)$ was then calculated from the survival curves using GraphPad Prism 5 (San Diego, CA, USA).

Cell cycle analysis by FACS. The tumor cells were seeded $\left(2 \times 10^{5}\right.$ cells/well) into six-well plates. Following overnight incubation, the medium was replaced with serum-free medium containing $50 \mu \mathrm{M} 5-\mathrm{FU}$ for $24 \mathrm{~h}$ for serum starvation and incu- bated for 12, 24 or $48 \mathrm{~h}$. Starving the cells of serum prior to treatment arrests them at the G1/S phase of the cell cycle for synchronization in order to minimize spectral differences at $1,080 \mathrm{~cm}^{-1}$, which can be attributed to cells being in different phases of the cell cycle (21-23). The cells were then harvested and stained with propidium iodide (PI) for cell cycle and apoptotic analysis using standard FACS techniques with a FACSort flow cytometer (BD Biosciences, Franklin Lakes, NJ, USA) according to the manufacturer's instructions. The results were analyzed and expressed as percentages of the total gated cells using Modifit LT ${ }^{\mathrm{TM}}$ software (BD Biosciences).

Isolation of nuclei. The SW620 cells were harvested by scraping the plates in cold PBS and were collected by centrifugation at $666 \mathrm{x}$ g. The cells were then resuspended in three volumes with respect to the cell pellet of the hypotonic buffer CelLytic $^{\mathrm{TM}} \mathrm{NuCLEAR}^{\mathrm{TM}}$ Extraction kit (Sigma, USA) (24). Following incubation on ice for $15 \mathrm{~min}, 5 \%$ Triton X-100 was added and a cytosolic fraction was prepared by centrifuging the sample for $30 \mathrm{sec}$ at $4^{\circ} \mathrm{C}$ at $1,498 \mathrm{x}$ g and subsequently clarified by centrifugation at $666 \mathrm{x}$ for $15 \mathrm{~min}$ at $4^{\circ} \mathrm{C}$. The nuclear pellets were washed twice in hypotonic buffer to remove any residual cytosolic contamination and then resuspended in one volume of nuclear lysis buffer. The cells were then incubated for $30 \mathrm{~min}$ at $4^{\circ} \mathrm{C}$ with gentle agitation and finally centrifuged for $30 \mathrm{~min}$ at $4^{\circ} \mathrm{C}$ at $1,498 \mathrm{x} \mathrm{g}$.

FTIR microspectroscopy (MSP) collection. FTIR-MSP is similar to visible light microscopy; however, it does not use glass refractive elements (glass is opaque to infrared light of $\lambda>5 \mu \mathrm{m}$ ) (12). For this reason, microtransmission FTIR requires samples to be deposited on optical windows, such as $\mathrm{CaF}_{2}$, which do not absorb infared light $(25,26)$. The FTIR spectrometer was equipped with a liquid nitrogen-cooled mercury cadmium telluride (MCT) detector and a $\mathrm{KBr}$ beam splitter (Thermo Nicolet 6700; Thermo Fisher Scientific, Waltham, MA, USA). All cells were grown on a $\mathrm{CaF}_{2}$ window film. A blank $\mathrm{BaF}_{2}$ window-film was scanned as background and the sample was then scanned. To collect the data for each spectrum, 32 scans were performed in the mid-infrared range (wave number, 4,000-900 $\mathrm{cm}^{-1}$ ) at a resolution of $8 \mathrm{~cm}^{-1}$.

Statistical analysis. OMNIC 8.0 (Thermo Fisher Scientific) was used as data-processing software for FTIR spectrum analysis (27). The five point moving average smoothing method was used for each spectrum to reduce random noise. The intensity and peak position of each band was measured using Spapro version 2.2 software (College of Chemistry and Molecular Engineering, Peking University, Beijing, China). All experiments were repeated at least three times. The statistical significance of the differences were evaluated by one way analysis of variance and $\mathrm{P}<0.05$ was considered to indicate a statistically significant difference.

\section{Results}

Concentration of 5-FU. Following treatment of the SW620 cells with increasing concentrations of 5-FU, cell growth was inhibited to different degrees and concentration-dependent cell toxicity was observed (Fig. 1). The $\mathrm{IC}_{50}$ data indicated 
Table I. Band assignments of major absorptions in the Fourier transform infrared spectra of the SW620 cells in the 4,000-900 $\mathrm{cm}^{-1}$ region.

\begin{tabular}{|c|c|c|}
\hline Peak number & Frequency $\left(\mathrm{cm}^{-1}\right)$ & Assignments \\
\hline 1 & 3,290 & $v_{\mathrm{O}-\mathrm{H},} v_{\mathrm{N}-\mathrm{H}}($ water, protein $)$ \\
\hline 2 & 2,925 & $\mathrm{C}$-H stretching bands $v_{\text {as }} \mathrm{CH}_{2}$ (lipid) \\
\hline 3 & 2,852 & $v_{\mathrm{s}} \mathrm{CH}_{2}$ of lipids \\
\hline 4 & 1,740 & $\mathrm{C}=\mathrm{O}$ stretching bands (lipids) \\
\hline 5 & 1,640 & Amide I (of proteins in $\alpha$-helix conformation) and water \\
\hline 6 & $1,540-1,580$ & Amide II (an N-H bending vibration coupled to C-N stretching) \\
\hline 7 & 1,454 & $\mathrm{CH}_{3}$ bending vibration (lipids and proteins) \\
\hline 8 & 1,410 & $\delta \mathrm{C}-\mathrm{H}, \delta \mathrm{C}-\mathrm{O}-\mathrm{H}$, amino acid residues \\
\hline 9 & $1,310-1,320$ & Amide III band components of proteins \\
\hline 10 & 1,240 & Asymmetric $\mathrm{PO}_{2}^{-}$stretching in RNA \\
\hline 11 & 1,121 & $\mathrm{C}-\mathrm{O}(\mathrm{H})$ stretching bands, threonine and tyrosine \\
\hline 12 & $1,080-1,085$ & $\begin{array}{l}\mathrm{C}-\mathrm{O}-\mathrm{C} \text { stretching (nucleic acids and phospholipids) } \\
\text { indicates a degree of oxidative damage to DNA }\end{array}$ \\
\hline 13 & 1,040 & C-O stretching bands, nucleic acid molecule polysaccharide \\
\hline
\end{tabular}

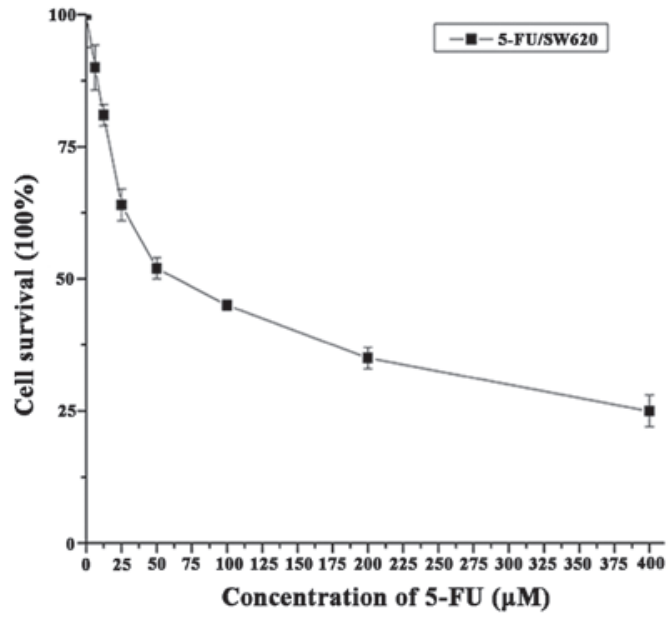

Figure 1. Proliferative activity of the 5-FU-treated SW620 cells at 5-FU concentrations of $6.25,12.5,25,50,100,200$ and $400 \mu \mathrm{M}$, assessed after $24 \mathrm{~h}$ using an MTT assay. The y-axis represents the cell survival, calculated as the ratio between the 5-FU-treated and control cells. 5-FU, 5-fluorouracil.

the 5-FU-resistance levels of the SW-620 cells at $\mathrm{IC}_{50} 50 \mu \mathrm{M}$ (Fig. 1). Therefore, $50 \mu \mathrm{M} 5$-FU was selected as the concentration for use in the subsequent experiments.

Sw620 cells arrest at the $G 1$ and S phase. The SW620 cells were serum-starved and analyzed by flow cytometry following PI staining, which resulted in S and G1 phase cell cycle arrest with $90 \%$ cells in the G1+S phases as compared with $77 \%$ in the control (Fig. 2). Compared with the control, S and G1 phase arrest in the serum-starved SW-620 cells was significantly increased $(\mathrm{P}<0.05)$.

Apoptosis induced by 5-FU. Treatment with 5-FU induced SW620 cell apoptosis. The population of apoptotic cells was evaluated by FACS using Annexin V/PI staining following 5 -FU treatment at $50 \mu \mathrm{M}$ for 12,24 and $48 \mathrm{~h}$. Annexin $\mathrm{V}$ is

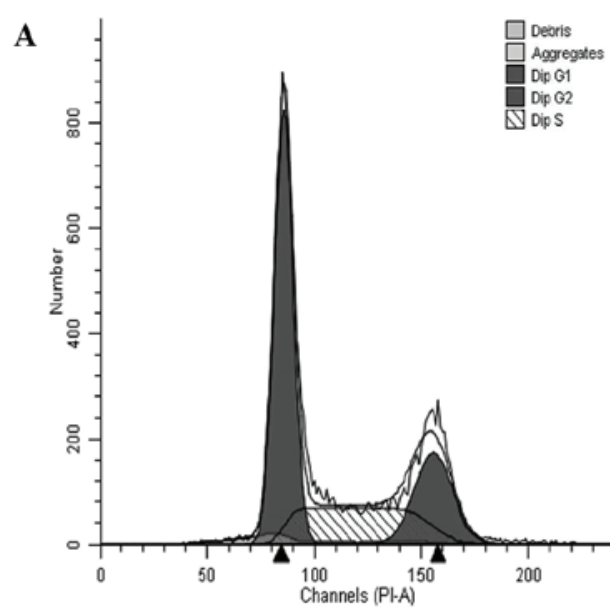

B

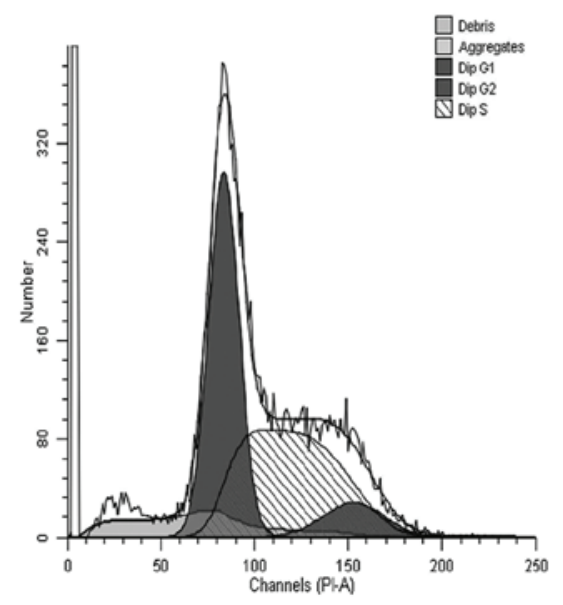

Figure 2. Cell cycle arrest at the G1/S phase was evaluated by fluorescence activated cell sorting using Annexin V/PI staining in the SW620 cells in the (A) control and (B) following serum-starving. PI, propidium iodide.

a $\mathrm{Ca}^{2+}$-dependent phospholipid binding protein, which can combine with the apoptotic cell valgus membrane, and PI is a nucleic acid-binding dye. PI can distinguish between early 
A

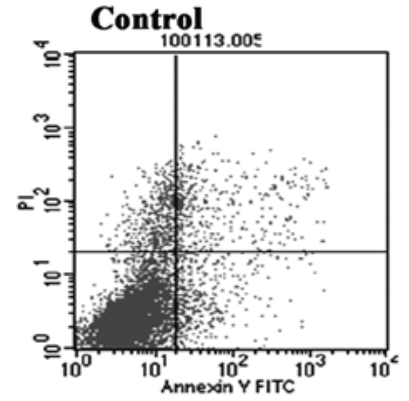

D

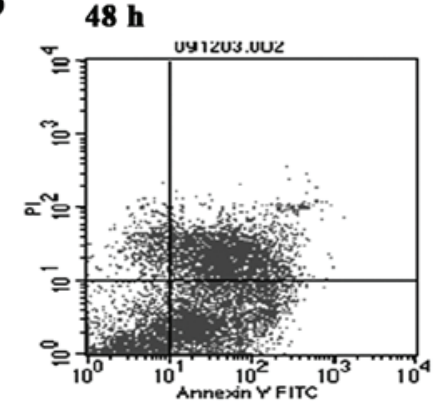

B

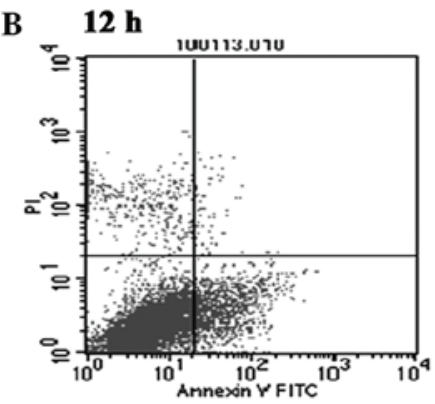

E

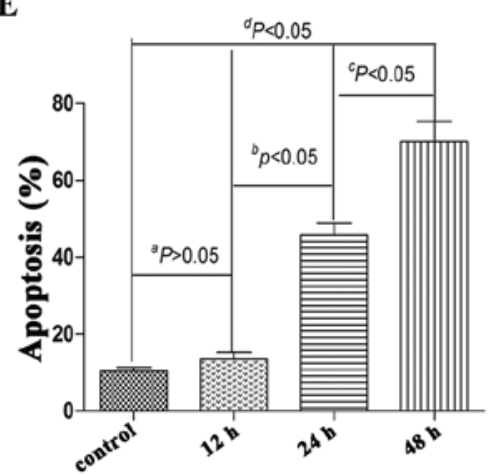

C

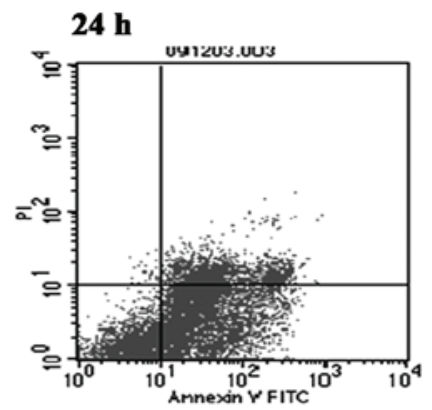

Time

Figure 3. Apoptosis in the (A) control SW620 cells and in SW620 cells induced by 5-FU (50 $\mu \mathrm{M}$ ) for (B) $12 \mathrm{~h}$ (C) $24 \mathrm{~h}$ and (D) $48 \mathrm{~h}$ compared with the control. (E) Quantification of apoptosis in the SW620 cells. ${ }^{a} 12 \mathrm{~h}$, vs. control; ${ }^{\mathrm{b}} 24 \mathrm{~h}$, vs. $12 \mathrm{~h}$; ${ }^{\mathrm{c}} 48 \mathrm{~h}$, vs. $24 \mathrm{~h}$; ${ }^{\mathrm{d}} 48$ and $24 \mathrm{~h}$ vs. $12 \mathrm{~h}$ and control. 5-FU, 5-fluorouracil.

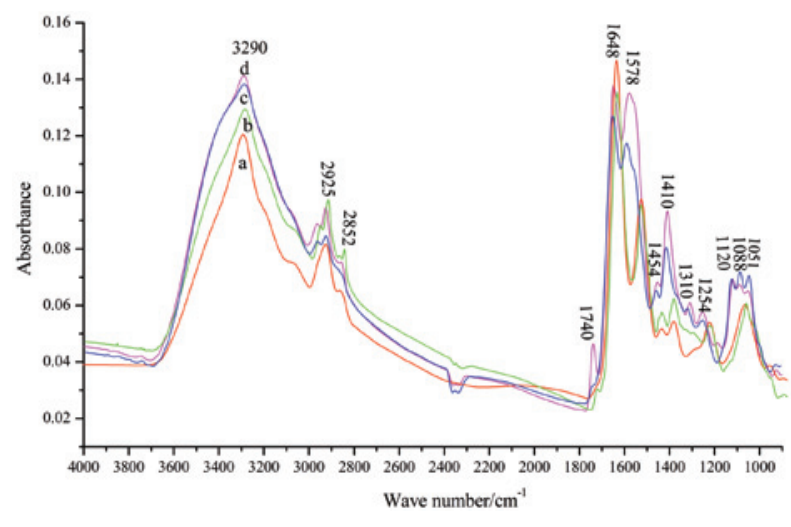

Figure 4. Fourier transform infrared spectra at wave numbers 4,000 and $900 \mathrm{~cm}^{-1}$. (a) Untreated SW620 cells (control). (b, c and d) SW620 cells treated with $50 \mu \mathrm{M} 5-\mathrm{FU}$ for 12,24 and $48 \mathrm{~h}$, respectively.

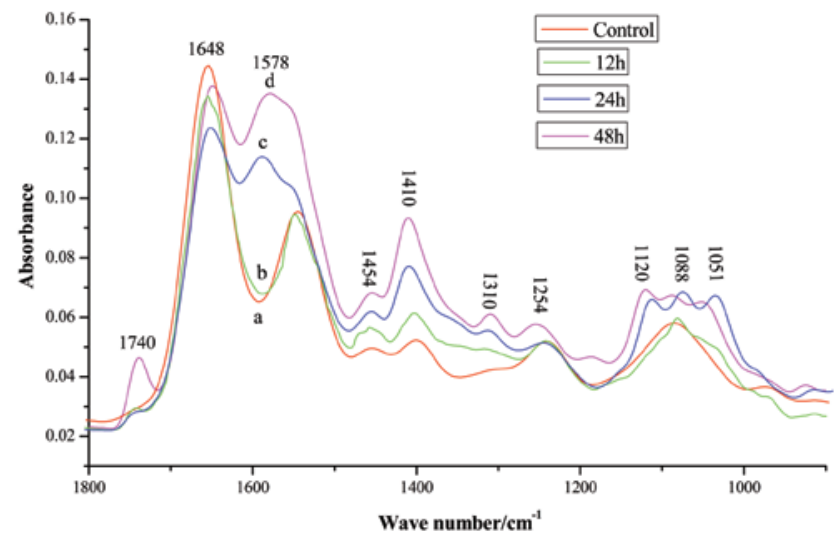

Figure 5. Fourier transform infrared spectra in the 1,800 and $900 \mathrm{~cm}^{-1}$ wave number region in the (a) control SW620 cells and (b-d) in the SW620 cells treated with 5 -fluorouracil for (b) $12 \mathrm{~h}$, (c) $24 \mathrm{~h}$ and (d) $48 \mathrm{~h}$.

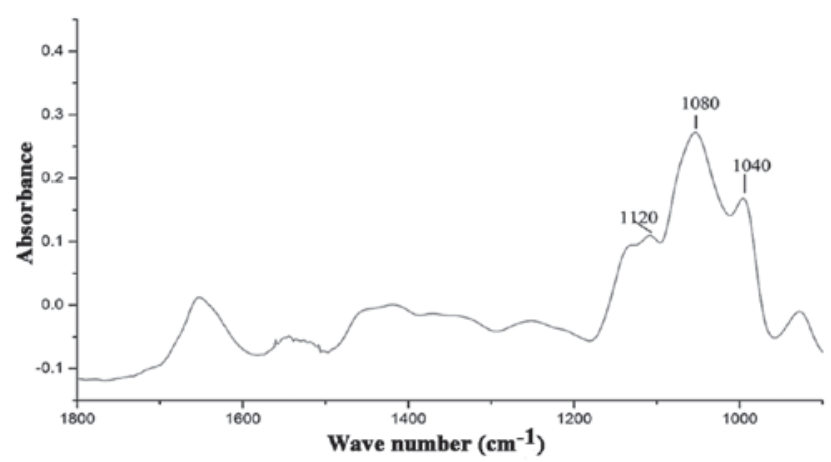

Figure 6. Fourier transform infrared spectra of the SW620 cell nuclei in the $1,800-900 \mathrm{~cm}^{-1}$ wave number region.

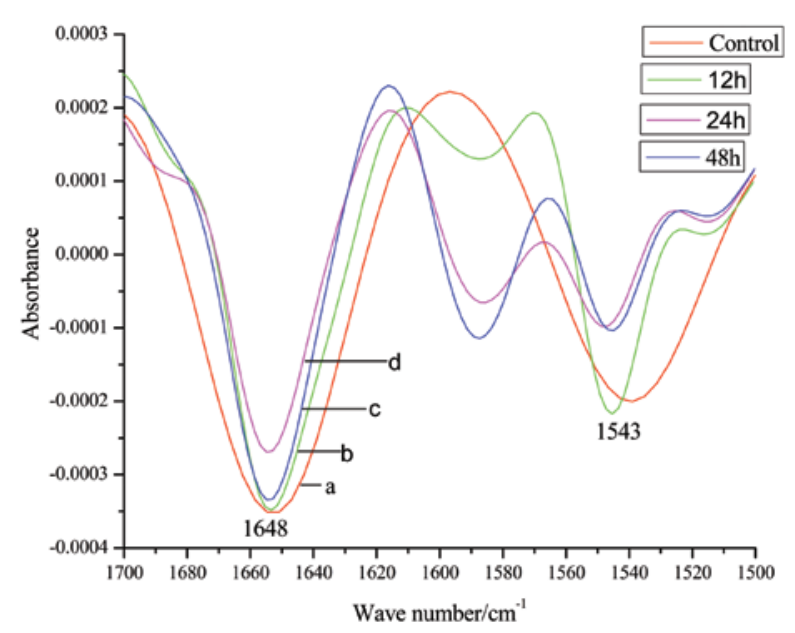

Figure 7. Derivative spectra of the $1,700-1,400 \mathrm{~cm}^{-1}$ region. (a) Control SW620 cells and (b-d) in the SW620 cells treated with 5-fluorouracil for (b) $12 \mathrm{~h}$, (c) $24 \mathrm{~h}$ and (d) $48 \mathrm{~h}$. 

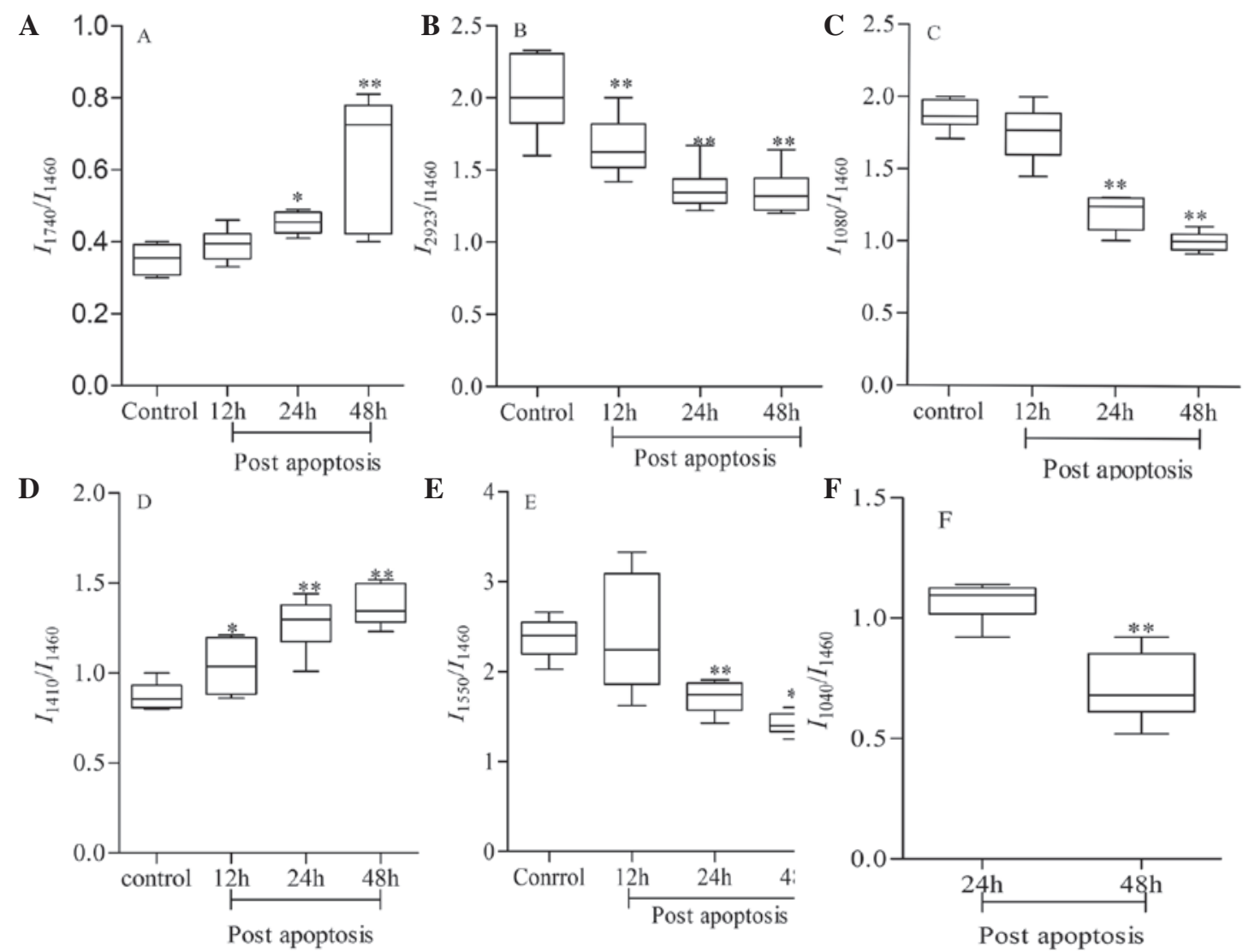

Figure 8. Statistical analysis of Fourier transform infrared relative intensity ratios $\left(/ I_{1460}\right)$ of the control SW620 cells and the cells treated with 5-fluorouracil for 12,24 and $48 \mathrm{~h}$ using one-way analysis of variance. (A) $I_{1740} / I_{1460}$, (B) $I_{2923} / I_{1460}$, (C) $I_{1080} / I_{1640}$, (D) $I_{1410} / I_{1640}$, (E) $I_{1550} / I_{1640}$ and (F) $I_{1040} / I_{1640}$. Boxes and error bars represent median, interquartile range and range, respectively. $\mathrm{P}<0.05$, compared with the control, ${ }^{* * *} \mathrm{P}<0.001$, compared with 12 and $24 \mathrm{~h}$.
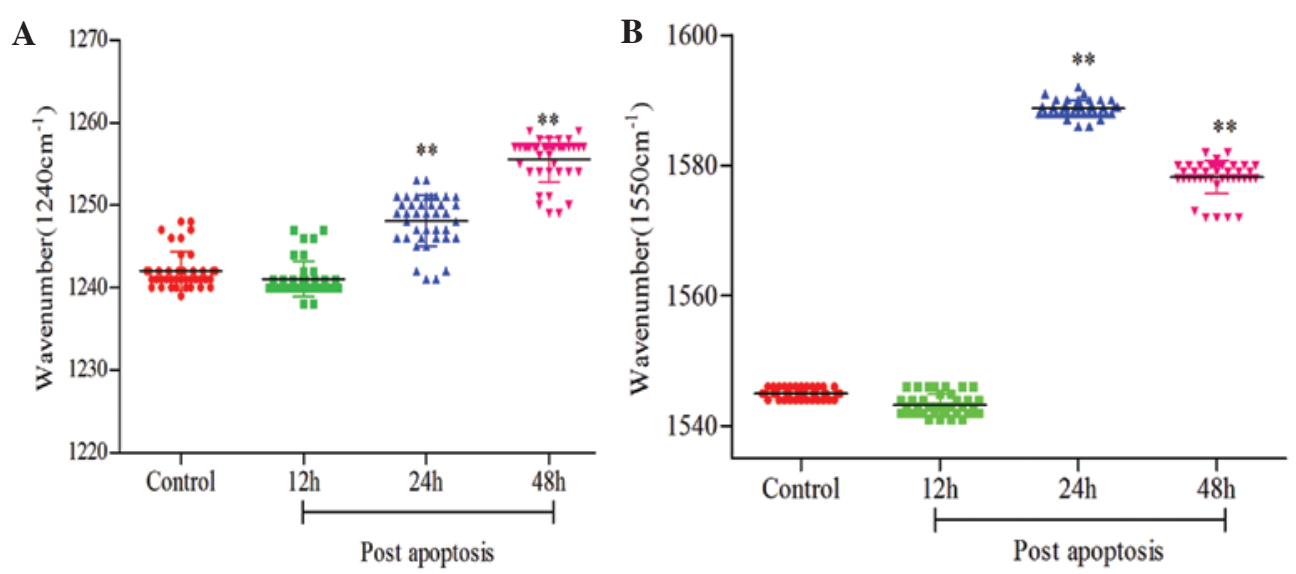

Figure 9. (A and B) Fourier transform infrared spectrum peak position comparisons between the control cells and the cells treated with 5-fluorouracil for 12, 24 and $48 \mathrm{~h}$ using one-way analysis of variance. ${ }^{* *} \mathrm{P}<0.001$ compared with the control.

and late stage apoptosis using FACS. The percentage of Annexin V-positive apoptotic cells increased following 5-FU treatment compared with that of the control $(10.04 \pm 2.1 \%$; Fig. 3A), for 12 h (Fig. 3B; 13.74 $\pm 3.2 \%$ ), 24 h (Fig. 3C;

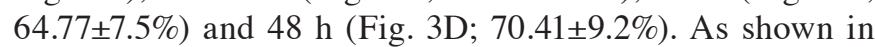
Fig. 3E, a significant increase in apoptosis was observed between the control and $12 \mathrm{~h}, 12$ and $24 \mathrm{~h}$ (early apoptosis) and between 24 and $48 \mathrm{~h}$ (late apoptosis).
FTIR-MSP spectral analysis. The absorbance spectra of the SW620 cells from the control group and the cells treated with 5-FU for 12, 24 and $48 \mathrm{~h}$ are shown in Fig. 4. The appearance of two new bands occurred at $24 \mathrm{~h}$ (Fig. 4C) at $1,120 \mathrm{~cm}^{-1}$ and $1,080 \mathrm{~cm}^{-1}$, respectively. Relevant absorbance bands in the FTIR spectra are shown in Fig. 5, between the fingerprint region of 1,800 and $900 \mathrm{~cm}^{-1}$. The new bands, which appeared at $24 \mathrm{~h}$, were further examined by extraction of the nuclei of 
the SW620 cells to confirm whether $1,120 \mathrm{~cm}^{-1}$, representing threonine (Thr) and serine (Ser) and $1,080 \mathrm{~cm}^{-1}$ (nucleic acid molecule polysaccharide) were present in the nuclei (Fig. 6). The band assignments are shown in Table I. The second derivative spectra of $1,700-1,400 \mathrm{~cm}^{-1}$ in Fig. 7 were used to investigate amide I and amide II and the FTIR results were analyzed between the 4,000 and $900 \mathrm{~cm}^{-1}$ spectral regions.

Band changes are associated with lipids. The changes in the relative intensity ratios of the main functional groups are shown in Fig. 8. The bands associated with cell lipids occurred mainly at 2,925,2,852 and $1,740 \mathrm{~cm}^{-1}$. The 2,925 and $2,852 \mathrm{~cm}^{-1}$ spectral features were absorption bands of asymmetric and symmetric $\mathrm{C}-\mathrm{H}$ stretching vibrations of $\mathrm{CH}_{2}$ and $\mathrm{CH}_{3}$ methylene groups, which are contained in fatty acids in cellular membranes (28). The band at $1,740 \mathrm{~cm}^{-1}$ is a $\mathrm{C}=\mathrm{O}$ stretching vibration. Changes in these bands can reflect lipid changes in tissues and cells (29). Late apoptosis (48 h) was associated with large lipid-associated peaks $\left(1,743 \mathrm{~cm}^{-1}\right)$, the relative intensity ratios $I_{1740} / I_{1460}$ were significantly increased after $48 \mathrm{~h}$ compared with those of the control, 12 and $24 \mathrm{~h}$ groups, with an increase between $0.34 \pm 0.03$ and $0.77 \pm 0.04$ $(\mathrm{P}<0.001$; Fig. 8A), whereas the relative intensity ratio $I_{2923} / I_{1460}$ was significantly decreased after $48 \mathrm{~h}$ compared with those of the control and the 12 and $24 \mathrm{~h}$ groups, which may indicate that the degree of apoptotic cell methylation decreased (Fig. 8B).

Band changes are associated with nucleic acids. The two major bands in the regions of 1,080 and $1,240 \mathrm{~cm}^{-1}$ are mainly due to the symmetric and asymmetric stretching modes of the phosphodiester groups $(30,31)$. These two bands are associated with the nucleic acid content of a cell (32). The ratio of intensities at the absorption $I_{1080} / I_{1640}$ began to decrease at $12 \mathrm{~h}$ and the ratio was significantly lower at $48 \mathrm{~h}(\mathrm{P}<0.001$; Fig. 8C), with late apoptotic DNA degraded into small fragments. The morphological results of the apoptotic bodies from the phagocytosis of DNA fragments morphological results coincided with this. The band at the $1,080 \mathrm{~cm}^{-1}$ absorption peak shifted to lower wave numbers at 12 and $24 \mathrm{~h}$; however, the shift to a higher wavenumber at $48 \mathrm{~h}$ may have been due to enhancement of hydrogen bonds in the late apoptotic stage (Fig. 9A). Further investigation is required to investigate the underlying causes.

Band changes are associated with amino acids. The vibrational bands at $1,120 \mathrm{~cm}^{-1}$ appeared at $24 \mathrm{~h}$ (early apoptosis) and increased at $48 \mathrm{~h}$ (late apoptosis) compared with those in the other groups. The $1,120 \mathrm{~cm}^{-1}$ absorption band was mainly due to ser, thr and tyrosine $\mathrm{C}-\mathrm{O}(\mathrm{H})$ stretching vibration (Figs. 4C and D and 5). FACS can detect apoptotic cells as Annexin $\mathrm{V}$ has a high affinity for phosphatidylserine. Fig. 3E shows Annexin $\mathrm{V}$ binding at the different stages of apoptosis (24 and $48 \mathrm{~h}$ ). Annexin $\mathrm{V}$ binding to phosphatidylserine increased over time, indicating that ser increased the exposure of phosphatidylserine on the outer lipid layer, consistent with the FTIR spectra results.

The band at the $1,410 \mathrm{~cm}^{-1}$ peak, which represents $\mathrm{C}-\mathrm{H}$ stretching-associated amino acid residues, shifted to higher wave numbers compared with those in the other groups (Fig. 8D) .
Band changes are associated with amide I and II. In all spectra, major peaks were observed for absorptions in the amide I and amide II regions at 1,640 and $1,550 \mathrm{~cm}^{-1}$, respectively. The vibrational band at $1,640 \mathrm{~cm}^{-1}$ was primarily characterized by the $\alpha$-helix secondary structure of the proteins (33) and the absorption bands at $1,550 \mathrm{~cm}^{-1}$ were attributed to the $\beta$-sheet secondary structure of proteins (34). As shown in Fig. 7, the spectral intensity at 1,640 and $1,550 \mathrm{~cm}^{-1}$ decreased in the second order derivative spectra of the region of 1,700-1,400 $\mathrm{cm}^{-1}$ at early and late stages of apoptosis. This decrease in intensity indicated that the $\alpha$-helix and $\beta$-sheet contents of the apoptotic cells decreased. The relative peak intensity ratio $I_{1543} / I_{1460}$ increased significantly, indicating that the hydrogen bond constraint was reduced (Fig. 8E) and the band at $1,550 \mathrm{~cm}^{-1}$ shifted to higher wave numbers at 24 and $48 \mathrm{~h}$ (Fig. 9B).

Band changes are associated with polysaccharides. The absorption band at $1,040 \mathrm{~cm}^{-1}$ was mainly due to the polysaccharide $\mathrm{C}-\mathrm{O}$ stretching vibration arising in early apoptosis (35); however, the peak intensity decreased in late apoptosis (Fig. 8F), suggesting that polysaccharides decreased in late apoptotic cells.

\section{Discussion}

The present study demonstrated that the FTIR-MSP spectral pattern of cells of the SW620 human colon cancer cell line reflects their apoptotic stage. On comparison of the spectral analysis with the FACS data, the most obvious differences were observed between $24 \mathrm{~h}$ (early apoptosis) and $48 \mathrm{~h}$ (late apoptosis). Flow cytometric data revealed that the number of apoptotic cells increased significantly after $24 \mathrm{~h}$ and $48 \mathrm{~h}$ compared with the cells in the control group and at $12 \mathrm{~h}$.

Apoptosis was characterized by changes in four IR biomarkers: Increased lipid content and absorbance of ser and thr at $1,740 \mathrm{~cm}^{-1}$ and decreased DNA absorbance, decreased $\alpha$-helix and $\beta$-sheet secondary structures of total cellular proteins within the apoptotic cells, the appearance of new vibrational bands at 1,120 and $1,040 \mathrm{~cm}^{-1}$ at $24 \mathrm{~h}$ with a decrease in the band at $1,040 \mathrm{~cm}^{-1}$, associated with polysaccharide absorbance at $48 \mathrm{~h}$ and an increase in amino acid residues.

Despite several tools to monitor and assess the curative effect of chemotherapy on cancer, colon cancer remains the most frequent cause of mortality in cancer patients. Thus, the investigation of techniques to monitor colon cancer chemotherapy is of clinical importance.

Compared with established techniques, the IR method is relatively inexpensive, fast and can be automated with no reagents. In conclusion, the present study demonstrated that FTIR spectroscopy can distinguish cell apoptosis based on changes in DNA conformation and protein secondary structure, particularly alteration in amino acid residues. This may provide a promising novel tool to monitor cell death in cancer chemotherapy clinically.

\section{Acknowledgements}

The authors would like to thank the National Nature Science Foundation of China (nos. 81172362 and 81101874) and the 
Co-ordinative and Innovative Plan Projects of the Science and Technology Project of Shaanxi Province (no. 2013KTCQ03-08) for supporting this work. The authors would also like to thank Dr Yuanfu Zhang (College of Chemistry and Molecular Engineering, Peking University, Beijing, China) and Dr Shifu Weng for their assistance and advice during the collection and processing of samples.

\section{References}

1. Tricoli JV, Seibel NL, Blair DG, Albritton K and Hayes-Lattin B Unique characteristics of adolescent and young adult acute lymphoblastic leukemia, breast cancer, and colon cancer. J Natl Cancer Inst 103: 628-635, 2011.

2. Kushi LH, Byers T, Doyle C, et al: American cancer society guidelines on nutrition and physical activity for cancer prevention: reducing the risk of cancer with healthy food choices and physical activity. CA Cancer J Clin 56: 254-281, 2006.

3. Zhao P, Dai M, Chen W and Li N: Cancer trends in china. Jpn J Clin Oncol 40: 281-285, 2010.

4. Sasaki K, Tsuno NH, Sunami E, et al: Chloroquine potentiates the anti-cancer effect of 5-fluorouracil on colon cancer cells. BMC Cancer 10: 370, 2010.

5. Folprecht $\mathrm{G}$ and Kohne $\mathrm{CH}$ : The role of new agents in the treatment of colorectal cancer. Oncology 66: 1-17, 2004.

6. Stelling AL, Toher D, Uckermann O, et al: Infrared spectroscopic studies of cells and tissues: triple helix proteins as a potential biomarker for tumors. PLoS One 8: e58332, 2013.

7. Wyatt MD and Wilson DM 3rd: Participation of DNA repair in the response to 5-fluorouracil. Cell Mol Life Sci 66: 788-799, 2009.

8. Rudin CM and Thompson CB: Apoptosis and disease: regulation and clinical relevance of programmed cell death. Annu Rev Med 48: 267-281, 1997.

9. Chowdhury I, Tharakan B and Bhat GK: Current concepts in apoptosis: the physiological suicide program revisited. Cell Mol Biol Lett 11: 506-525, 2006.

10. Hengartner MO: The biochemistry of apoptosis. Nature 407: 770-776, 2000

11. Deng N, Zheng L, Liu F, Wang L and Duan H: crcTRP: a translational research platform for colorectal cancer. Comput Math Methods Med 2013: 930362, 2013.

12. Bellisola G and Sorio C: Infrared spectroscopy and microscopy in cancer research and diagnosis. Am J Cancer Res 2: 1-21, 2012

13. Cheheltani R, Rosano JM, Wang B, Sabri AK, Pleshko N and Kiani MF: Fourier transform infrared spectroscopic imaging of cardiac tissue to detect collagen deposition after myocardial infarction. J Biomed Opt 17: 056014, 2012.

14. Lewis PD, Lewis KE, Ghosal R, et al: Evaluation of FTIR spectroscopy as a diagnostic tool for lung cancer using sputum. BMC Cancer 10: 640, 2010.

15. Taylor SE, Cheung KT, Patel II, et al: Infrared spectroscopy with multivariate analysis to interrogate endometrial tissue: a novel and objective diagnostic approach. Br J Cancer 104: 790-797, 2011.

16. Banyay M, Sandbrink J, Stromberg R and Graslund A: Characterization of an RNA bulge structure by fourier transform infrared spectroscopy. Biochem Biophys Res Commun 324: 634-639, 2004

17. Downes A, Mouras R and Elfick A: Optical spectroscopy for noninvasive monitoring of stem cell differentiation. J Biomed Biotechnol 2010: 101864, 2010.
18. Gasparri F and Muzio M: Monitoring of apoptosis of HL60 cells by fourier-transform infrared spectroscopy. Biochem J 369: 239-248, 2003

19. Zelig U, Kapelushnik J, Moreh R, Mordechai S and Nathan I: Diagnosis of cell death by means of infrared spectroscopy. Biophys J 97: 2107-2114, 2009.

20. Fanciullino R, Giacometti S, Mercier C, et al: In vitro and in vivo reversal of resistance to 5-fluorouracil in colorectal cancer cells with a novel stealth double-liposomal formulation. Br J Cancer 97: 919-926, 2007.

21. Flower KR, Khalifa I, Bassan P, et al: Synchrotron FTIR analysis of drug treated ovarian A2780 cells: an ability to differentiate cell response to different drugs? Analyst 136: 498-507, 2011.

22. Holman HY, Martin MC, Blakely EA, Bjornstad K and McKinney WR: IR spectroscopic characteristics of cell cycle and cell death probed by synchrotron radiation based fourier transform IR spectromicroscopy. Biopolymers 57: 329-335, 2000.

23. Hammiche A, German MJ, Hewitt R, Pollock HM and Martin FL: Monitoring cell cycle distributions in MCF-7 cells using near-field photothermal microspectroscopy. Biophys J 88: 3699-3706, 2005.

24. Ambrosino C, Tarallo R, Bamundo A, et al: Identification of a hormone-regulated dynamic nuclear actin network associated with estrogen receptor alpha in human breast cancer cell nuclei. Mol Cell Proteomics 9: 1352-1367, 2010.

25. Wehbe K, Filik J, Frogley MD and Cinque G: The effect of optical substrates on micro-FTIR analysis of single mammalian cells. Anal Bioanal Chem 405: 1311-1324, 2013.

26. Bali R, Savino L, Ramirez DA, et al: Macroscopic domain formation during cooling in the platelet plasma membrane: an issue of low cholesterol content. Biochim Biophys Acta 1788: 1229-1237, 2009.

27. German MJ, Hammiche A, Ragavan N, et al: Infrared spectroscopy with multivariate analysis potentially facilitates the segregation of different types of prostate cell. Biophys J 90: 3783-3795, 2006

28. Toyran N, Lasch P, Naumann D, Turan B and Severcan F: Early alterations in myocardia and vessels of the diabetic rat heart: an FTIR microspectroscopic study. Biochem J 397: 427-436, 2006.

29. Fogarty SW, Patel, II, Trevisan J, et al: Sub-cellular spectrochemical imaging of isolated human corneal cells employing synchrotron radiation-based Fourier-transform infrared microspectroscopy. Analyst 138: 240-248, 2013.

30. Banyay M, Sarkar M and Graslund A: A library of IR bands of nucleic acids in solution. Biophys Chem 104: 477-488, 2003.

31. Mello ML and Vidal BC: Changes in the infrared microspectroscopic characteristics of DNA caused by cationic elements, different base richness and single-stranded form. PLoS One 7: e43169, 2012.

32. Batard E, Jamme F, Boutoille D, et al: Fourier transform infrared microspectroscopy of endocarditis vegetation. Appl Spectrosc 64: 901-906, 2010.

33. Abbott GW, Ramesh B and Srai SK: Interaction between soluble and membrane-embedded potassium channel peptides monitored by fourier transform infrared spectroscopy. PLoS One 7: e49070, 2012.

34. Mantsch HH, Choo-Smith L-Pi and Shaw RA: Vibrational spectroscopy and medicine: an alliance in the making. Vib Spectrosc 30: 31-41, 2002.

35. Gautam R, Chandrasekar B, Deobagkar-Lele M, et al: Identification of early biomarkers during acetaminophen-induced hepatotoxicity by fourier transform infrared microspectroscopy. PLoS One 7: e45521, 2012. 